\title{
Comparison of Ketosis, Clinical Mastitis, Somatic Cell Count, and Reproductive Performance between Free Stall and Tie Stall Barns in Norwegian Dairy Herds with Automatic Feeding
}

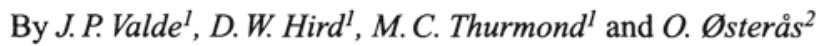

${ }^{1}$ Department of Medicine and Epidemiology, University of California, Davis, USA, and ${ }^{2}$ Norwegian Dairies Association, Ås, Norway.

\begin{abstract}
Valde, J. P., D.W. Hird, M.C. Thurmond and O. Østerås: Comparison of ketosis, clinical mastitis, somatic cell count, and reproductive performance between free stall and tie stall barns in norwegian dairy herds with automatic feeding. Acta vet. scand. 1997, 38, 181-192. - Differences in ketosis and clinical mastitis rates, mean somatic cell counts (SCC) and reproductive performance scores (fertility status index = FS-index) between herds housed in free stall $(n=533)$ and tie stall $(n=59)$ barns were measured in relation to management and environmental factors in a retrospective cohort study of Norwegian dairy farms with automatic grain feeding systems. Herds with tie stalls were found to have a higher clinical mastitis rate, $(61.6$ cases per 100 cow-years versus 46.4 cases per 100 cow-years $(p<0.01)$ ); a significantly higher proportion of herds with ketosis, (relative risk $=1.59,(\mathrm{p}<0.01)$ ); and a lower mean fertility status index, $(67.3$ versus $82.8(p<0.01))$. No significant difference in mean SCC was found between the 2 groups of dairies $(p=0.32)$. Large herds had higher $\log _{e}$ geometric mean SCC than small herds $(\mathrm{p}<0.01)$ and herds with high SCC had lower milk production than herds with low SCC $(p<0.01)$. Herds that scored "very good" on cow cleanliness had significantly lower adjusted mean SCC than herds with scores of "average" or "good" $(\mathrm{p}<0.05)$. Herds in barns with a concrete floor had an adjusted mean number of cases of clinical mastitis of 51.4 per 100 cow-years, 14 per cent higher than herds in barns with rubber mats, litter bed or wood ( 45.2 cases per 100 cow-years) $(\mathrm{p}<0.05)$. Herds with high milk production level had higher FS-index than herds with low milk production $(\mathrm{p}<0.01)$. Lower disease rates and the higher fertility status measured in the present study favor free stall herds over tie stall herds.
\end{abstract}

bovine; environment; management; cattle; housing; Norway.

\section{Introduction}

Free stall and tie stall barns are the 2 principal types of housing systems in Norwegian dairy herds. Although most dairies have tie stall barns, an increasing number of free stall barns has been built recently in an attempt to improve cow environment, well-being and production performance. Today, even farmers with small herds renovate their barns by changing to the free stall system. Higher disease rates have been suggested for tie stall barns compared to free stall barns, but few studies have been conducted in Norway to compare disease rates for the 2 types of barns. If considerable differences in disease rates really exist between the 2 systems, this should be taken into account when 
evaluating system operating costs. Information on differences in rates of diseases will thus be necessary to assess relative cost advantages of the 2 types of barns.

Mastitis and ketosis are the 2 most common diseases in Norwegian dairies, both of which represent a large financial loss because of discarded milk, treatment costs and decreased milk production. Although less clinical mastitis has been found in free stall housing systems than in herds with tie stalls (Bakken 1981), the relationship between potential confounding factors such as feeding procedure, hygiene, floor type, use of litter, and disease in free stall systems has not been assessed statistically due to the small number of herds with free stalls. Bovine mastitis, the most common disease of Norwegian dairy cows, is considered to be highly influenced by the environment, and up to $25 \%$ of the variation in subclinical mastitis between herds has been attributed to variation in the cows' environment (Bakken 1982).

Ketosis is the second most common disease of Norwegian dairy cows, with an estimated incidence of 18.4 cases per 100 cow-years reported to the Dairy Cow Recording System (DCRS) in 1994 (Østerås et al. 1994). Rates of ketosis might be affected by the different feeding system in the 2 types of barns. A major difference between free stall and tie stall systems is the grain feeding procedure. Most free stall barns have automatic grain feeding which makes it possible to distribute grain in small portions frequently during the day. Most tie stall barns utilize manual feeding 2 times a day. In one study, farms with manual grain feeding 3 times a day performed had a significantly lower treatment rate for ketosis compared with farms with twice-daily grain feeding (Rieman et al. 1985). A higher incidence of ketosis in the tie stall system compared to the free stall system could be due to differences in grain feeding procedure.
Another management problem that may be affected by barn design is estrus detection. The heat detection procedure and cow behavior during estrus are different when cows are tied to stalls than when they are free moving in the free stall system. Cows that are free-moving are more readily able to demonstrate estrous behavior, which would improve heat detection and, ultimately herd fertility.

The purpose of the retrospective observational cohort study presented here was to determine if differences existed in somatic cell count (SCC), clinical mastitis and ketosis rates, and reproductive performance scores (fertility status in$\mathrm{dex}=$ FS-index) between Norwegian herds with free stalls and herds with tie stalls, taking into account environmental and/or potential confounding factors.

\section{Materials and methods}

\section{Selection of herds}

As part of a collaborative project between the Norwegian Dairies Association (Norske Meierier) and the Royal Ministry of Agriculture, Department of Veterinary services, to study environmental conditions among Norwegian dairy farms, environmental and management data were collected from 3607 dairy herds in all counties of Norway. The herds consisted of a random selection from the Norwegian Dairies Association's data base, which contained all the dairy herds in the country, and in addition all known free stall barns and the free stall barns identified by the District Veterinary Officers (DVO) in their respective districts. The sample comprised approximately $14 \%$ of all dairy herds in Norway. For the present study we selected all the free stall and tie stall herds with automatic feeding of grain that took part in this survey and that were members of the Dairy Cow Recording System (Husdyrkontrollen). 
Table 1. Definitions of dependent and independent variables in the different regression models of $\log _{e}$ of somatic cell count ( $\mathrm{LnSCC}$ ), clinical mastitis rate and fertility status index (FS-index) on stall type and environmental and management factors in Norwegian dairy herds in free stall and tie stall barns in 1994.

\begin{tabular}{|c|c|}
\hline Variable Abbreviations & Definition \\
\hline \multicolumn{2}{|l|}{ Dependent variables: } \\
\hline LnSCC & $\begin{array}{l}\text { Logarithm of geometric mean somatic cell count (in } \\
1000 \text { per ml) from bulk milk. }\end{array}$ \\
\hline Clinical Mastitis & Number of reported cases of clinical mastitis per 100 cow years. \\
\hline FS-index ${ }^{a}$ & Fertility status index. \\
\hline \multicolumn{2}{|l|}{ Independent variables: } \\
\hline LnCowyear & Natural logarithm of number of cow years in the herd. \\
\hline Milk production & $\mathrm{Kg}$ milk produced per cow year. \\
\hline Culling rate & Number of culled cows per 100 cow years. \\
\hline Pasture & Per cent of total energy intake taken on pasture. \\
\hline Grain & Amount of grain in per cent of total energy intake. \\
\hline Year built & The year the barn was built or renewed. \\
\hline Type & Stall type, $(1=$ tie stall, $2=$ free stall $)$ \\
\hline Floor/Bedding & $\begin{array}{l}\text { Stall floor, }(1=\text { concrete, } 2=\text { rubber mat in some stalls and } \\
\text { concrete in others, } 3=\text { other })\end{array}$ \\
\hline Litter & Use of litter, ( 1 = litter used, 2 = no use of litter). \\
\hline Connection cellar & $\begin{array}{l}\text { Connection to dung cellar, }(1=\text { closed, } \\
2=\text { partially closed/open, } 3=\text { open })\end{array}$ \\
\hline Clean cow & Cow cleanliness $(1=$ very good, $2=$ good, $3=$ average, $4=$ poor $)$ \\
\hline Stall hygiene & Stall hygiene $(1=$ very good, $2=$ good, $3=$ average, $4=$ poor $)$. \\
\hline Hoof trimming & $\begin{array}{l}\text { Hoof trimming, }(1=\text { once a year, } 2=\text { twice a year, } \\
3=\text { when needed, } 4=\text { never. }) \text {. }\end{array}$ \\
\hline Hoof condition & Hoof condition, $(1=$ very good, $2=$ good, $3=$ average, $4=$ poor $)$ \\
\hline Clip cow & Are the cows clipped regularly? $(1=$ yes, $2=$ no. $)$. \\
\hline Barn insulation & Insulation of the barn ( 1 = good, $2=$ poor $)$. \\
\hline
\end{tabular}

a FS-index is defined in the "Materials and methods section".

\section{Description of herds}

During the 1990-91 season, 96 per cent of the cattle were artificially inseminated (Østerås 1993). Ninety-nine per cent of the dairy cows were Norwegian Red Cattle (NRC), and approximately one per cent were purebred or NRC crossed with Telemark, Blacksided or Jersey cattle.

\section{Environmental variables}

Information about environmental factors, including housing, management practices, hygiene and care, was obtained by means of a questionnaire administered by the DVO. All but 10 farms were visited between September 1994 and February 1995. The variables considered are listed in Table 1. Cow cleanliness, stall hy- 
Table 2. Definitions of scoring system used for evaluation of cow cleanliness, stall hygiene and hoof condition for Norwegian dairy herds in free stall or tie stall barns in 1994.

Grading Definition

Cow cleanliness ${ }^{\mathrm{a}}$ :

1. Very Good

2. Good

3. Average

4. Poor

Stall Hygiene:

1. Very Good

2. Good

3. Average

4. Poor

\section{Hoof Condition:}

1. Very Good

2. Good

3. Average

4. Poor
Clean and dry skin on all cows.

Some loose manure, or wet spot on a minority of the cows.

Most animals were partly dirty, or moist and dirty.

Very dirty or wet: Few cows were evaluated as being clean.

All stalls were clean and dry.

A few stalls were moist, but otherwise relatively clean. More than half of the stalls were characterized as clean.

Some of the stalls were dirty, and more than half were moist.

All stalls were dirty and moist. Only exceptionally were there

one or 2 clean stalls.

All hooves were perfect.

Some front hooves were deformed.

Most of the front hooves and some of the hind

hooves were deformed.

Most of the cows needed hoof trimming.

a Cow cleanliness was evaluated by cleanliness of thigh, udder and abdomen.

giene and hoof condition were evaluated by the DVO according to written, standardized instruction (Østerås 1991) (Table 2).

\section{Health variables}

Health information obtained from the DCRS represented data for 1994. For each cow, veterinarians recorded on a health card all diagnoses and treatments performed. The health card followed a cow all her life, and only veterinarians recorded diseases on these cards. Health card data were collected by personnel from the DCRS and reported monthly to the central data base.

Bulk milk samples were collected unannounced twice a month on each farm by the dairy trucker. The SCC was measured by the Fossomatic 360 at the regional milk laboratories and reported to the DCRS. The geometric mean
SCC for 1994 was calculated for each herd based on the 24 measurements. For purposes of analysis the natural logarithm of geometric mean SCC (LnSCC) was calculated to better approximate the normal distribution.

The clinical mastitis rate was defined as number of cases of clinical mastitis per 100 cowyears from January 1 through December 31, 1994 , and the ketosis rate was defined as number of treated cases of ketosis per 100 cowyears from January 1 through December 31, 1994.

Herd size was measured as number of cowyears (cowyear) in each herd and was defined as total number of cow-days (days from first calving or January 1 until slaughter or December 31) divided by 365 . The natural logarithm of number of cow years (LnCowyear) was calculated to better approximate the normal distribu- 
Fertility status (FS-index) is a measure of reproductive performance and was calculated on each farm according to the following formula:

$$
\text { FS-index }=\frac{[a / b-(c-125)]^{*}(e-d)}{e}
$$

$a=$ non return after 60 days $(\%)+\%$ of 2 or 3 inseminations in same estrus period.

$\mathrm{b}=$ number of services per inseminated cow or heifer.

$\mathrm{c}=$ average number of days between calving and last insemination.

$\mathrm{d}=$ number of cows culled because of infertility.

$\mathrm{e}=$ total number of inseminated cows or heifers.

FS-index less than 40 is considered poor, $40-80$ average and greater than 80 good.

\section{Statistical analysis}

The unit of statistical analysis was the herd. The hypotheses of no difference in clinical mastitis rates, LnSCC and FS-index between free stall and tie stall barns were tested by analysis of variance. Computations were performed using BMDP 7D (Dixon 1992). LnSCC, clinical mastitis and FS-index also were analyzed for possible predictor variables that could change the estimated presence or absence of difference in LnSCC, clinical mastitis and FS-index between free stall and tie stall barns by means of all-possible-regressions-procedure for variable reduction (Kleinbaum et al. 1987). Computations were performed by using BMDP 9R and $1 \mathrm{R}$. The following criteria were used for selecting variables to be evaluated by the models: the variables must be measurable in both the free stall and the tie stall barns; the relation between independent and dependent variables must make biological sense; the independent variables must not be highly correlated; and variables must not contain many missing values. The best models were selected based on adjusted $\mathrm{R}^{2}$ and Mallow's Cp (Kleinbaum et al. 1987). Categorical variables in the final models were tested for which categories were significant different from each other by using one-way analysis of covariance, adjusted for the variables in the respective models. Computations were performed using BMDP 1V.

Herds were categorized into those with reported cases of ketosis and those with no reported cases of ketosis; the difference between the free stall and tie stall herds with respect to ketosis was examined by Chi-square test.

\section{Results \\ Descriptive statistics}

The questionnaire reply rate was greater than 98 per cent and provided data for 533 free stall herds and 59 tie stall herds which fulfilled the inclusion criterion of automatic grain feeding. Descriptive statistics for herd health and environmental variables are given in Tables 3 and 4 . The distribution of cow-year was skewed with a kurtosis of 14.5. $\log _{\mathrm{e}}$ transformation, (LnCowyear), gave an approximately normal distribution with a kurtosis of 1.5 and mean of 2.8 and median of 2.7. No significant difference was found between the mean herd size of 18.1 cowyears for free stall barns and that of 16.6 cowyears for tie stall barns $(p=0.21)$.

\section{Somatic cell count}

No significant difference in mean LnSCC was found between free stall (4.950) and tie stall herds $(4.892)(p=0.32)$. Variables included in the final regression model of LnSCC are noted by their coefficients and p-values in Table 5 . Large herds had higher LnSCC than small herds $(\mathrm{p}<0.01)$ and herds with high SCC had lower milk production than herds with low SCC $(\mathrm{p}<0.01)$.

Table 6 illustrates the differences found in ad- 
Table 3. Descriptive statistics of continuous variables used in the regression models of $\log _{e}$ of somatic cell count (LnSCC), clinical mastitis rate or fertility status-index (FS-index) measured in Norwegian dairy herds in free stall or tie stall barns in 1994.

\begin{tabular}{|c|c|c|c|c|c|}
\hline \multirow{2}{*}{ Variable name ${ }^{a}$} & \multirow{2}{*}{$\begin{array}{c}\text { No } \\
\text { herds }\end{array}$} & \multirow{2}{*}{ Mean } & \multirow{2}{*}{$\begin{array}{c}\text { Standard } \\
\text { error }\end{array}$} & \multicolumn{2}{|c|}{ Range } \\
\hline & & & & Minimum & Maximum \\
\hline LnSCC & 592 & $4.9441^{b}$ & 0.0174 & $3.4554^{\mathrm{c}}$ & $6.4313^{c}$ \\
\hline Clinical mastitis & 592 & 47.9 & 1.37 & 0.0 & 234 \\
\hline FS-index & 592 & 81.2 & 1.09 & 0.0 & 174 \\
\hline LnCow year & 592 & $2.8046^{\mathrm{d}}$ & 0.0159 & $1.8083^{\mathrm{e}}$ & $4.5839^{\circ}$ \\
\hline Milk production & 592 & 6434 & 32.9 & 2129 & 8927 \\
\hline Culling rate & 592 & 46.7 & 0.73 & 0 & 121 \\
\hline Pasture & 592 & 11.9 & 0.36 & 0 & 43 \\
\hline Grain & 581 & 37.5 & 0.24 & 10 & 66 \\
\hline Year built & 587 & 1987 & 0.23 & 1960 & 1994 \\
\hline
\end{tabular}

a Variables are defined in Table 1.

b Corresponds to SCC of 140,350 cells per ml.

c Corresponds to 31,670 and 620,980 cells per $\mathrm{ml}$ respectively.

d Corresponds to 16.5 cow years.

e Corresponds to 6.1 and 97.9 cow years respectively.

justed mean LnSCC between the different categories of cow cleanliness. Herds scoring 'average' on cow cleanliness had adjusted mean SCC of 151,000 cells per ml, which was significantly higher than the 123,500 cells per $\mathrm{ml}$ for herds with score 'very good' $(p<0.05)$. Herds scoring 'poor' on cow cleanliness had the highest adjusted mean SCC (167,500 cells per ml), but the association was not significant because only 7 herds were given the 'poor' rating.

\section{Clinical mastitis}

Free stall barns had a mean clinical mastitis rate of 46.4 cases per 100 cow-years at risk, which was significantly lower than the mean clinical mastitis rate of 61.6 for tie stall barns. $(\mathrm{p}<0.001)$.

Variables included in the final regression model of clinical mastitis are noted by their coefficients and p-values in Table 5. Herds with high clinical mastitis rates had higher culling rate than herds with low clinical mastitis rates $(p<0.05)$. In the model, the regression coeffi- cient for type of barn $\left(\beta_{\text {Type }}=-16.8\right)$ was significant $(p<0.01)$, meaning that tie stall herds had a significantly higher adjusted mean clinical mastitis rate than free stall herds, as was also true for comparison of their crude means.

Table 7 illustrates the difference in adjusted mean clinical mastitis rates among the 3 different categories of floor/bedding. Herds in barns with concrete floors had an adjusted mean number of cases of clinical mastitis of 51.4, which was 14 per cent higher than herds whith cows on rubber mats, litter bed or wood (45.2 cases per 100 cow-years) $(p<0.05)$. Seventy-six per cent of tie stall barns had a concrete floor while only $42 \%$ of free stalls had solely concrete floors. The majority of free stall barns had floor/bedding classified as litter bedding (219 of $533=41 \%$ ), and $95 \%$ (207) of the litter beds consisted of sawdust or wood shavings.

\section{Fertility status}

Free stall herds had a mean FS-index of 82.8, which was significantly higher than that of 67.3 
Table 4. Description of categorical variables used in the regression models of $\log _{e}$ of somatic cell counts (LnSCC), clinical mastitis rates or fertility status-index (FS-index) measured in Norwegian dairy herds in free stall or tie stall barns in 1994.

\begin{tabular}{|c|c|c|c|}
\hline Variable name & Code $^{a}$ & Frequency & Definition \\
\hline Type & $\begin{array}{l}1 \\
2\end{array}$ & $\begin{array}{r}59 \\
533\end{array}$ & $\begin{array}{l}\text { Tie Stall Barn } \\
\text { Free Stall Barn }\end{array}$ \\
\hline Floor/Bedding & $\begin{array}{l}1 \\
2 \\
3\end{array}$ & $\begin{array}{r}265 \\
19 \\
305\end{array}$ & $\begin{array}{l}\text { Concrete } \\
\text { Rubber mat in some stalls else concrete } \\
\text { Other (all rubber mat }=77 \text {, litter bed }=219 \text {, wood }=7, \text { Other }=2 \text { ) }\end{array}$ \\
\hline Litter & $\begin{array}{l}1 \\
2\end{array}$ & $\begin{array}{r}527 \\
57\end{array}$ & $\begin{array}{l}\text { Litter used } \\
\text { No litter used }\end{array}$ \\
\hline Connection cellar & $\begin{array}{l}1 \\
2 \\
3\end{array}$ & $\begin{array}{r}157 \\
45 \\
386\end{array}$ & $\begin{array}{l}\text { Closed } \\
\text { Partially closed/open } \\
\text { Open }\end{array}$ \\
\hline Clean cow & $\begin{array}{l}1 \\
2 \\
3 \\
4\end{array}$ & $\begin{array}{r}108 \\
364 \\
110 \\
7\end{array}$ & $\begin{array}{l}\text { Very Good } \\
\text { Good } \\
\text { Average } \\
\text { Poor }\end{array}$ \\
\hline Stall hygiene & $\begin{array}{l}1 \\
2 \\
3 \\
4\end{array}$ & $\begin{array}{r}126 \\
331 \\
119 \\
12\end{array}$ & $\begin{array}{l}\text { Very Good } \\
\text { Good } \\
\text { Average } \\
\text { Poor }\end{array}$ \\
\hline Hoof trimming & $\begin{array}{l}1 \\
2 \\
3 \\
4\end{array}$ & $\begin{array}{r}143 \\
39 \\
304 \\
105\end{array}$ & $\begin{array}{l}\text { Once a year } \\
\text { Twice a year } \\
\text { When needed } \\
\text { Never }\end{array}$ \\
\hline Hoof condition & $\begin{array}{l}1 \\
2 \\
3 \\
4\end{array}$ & $\begin{array}{r}102 \\
371 \\
106 \\
5\end{array}$ & $\begin{array}{l}\text { Very Good } \\
\text { Good } \\
\text { Average } \\
\text { Poor }\end{array}$ \\
\hline Clip cow & $\begin{array}{l}1 \\
2\end{array}$ & $\begin{array}{l}255 \\
333\end{array}$ & $\begin{array}{l}\text { Regularly clipped } \\
\text { No regularly clipping }\end{array}$ \\
\hline Barn insulation & $\begin{array}{l}1 \\
2\end{array}$ & $\begin{array}{r}540 \\
52\end{array}$ & $\begin{array}{l}\text { Good } \\
\text { Poor }\end{array}$ \\
\hline Ketosis & $\begin{array}{l}0 \\
1\end{array}$ & $\begin{array}{l}351 \\
241\end{array}$ & $\begin{array}{l}\text { No cases of ketosis reported } \\
\text { Cases of ketosis reported }\end{array}$ \\
\hline
\end{tabular}

a Codes refer to the value each category was given in the analysis.

which was significantly higher than that of 67.3 for the tie stall herds. $(\mathrm{p}<0.001)$.

Variables included in the final model are noted by their coefficients and p-values in Table 8 . Herds with high milk production had higher
FS-index than herds with low milk production. $(\mathrm{p}<0.01)$. In the model, the coefficient for type of barn $\left(\beta_{\text {Type }}=14.8\right)$ was significant $(\mathrm{p}<0.01)$, meaning that free stall herds had a significantly higher adjusted mean FS-index than tie stall 
Table 5. Regression coefficients and significance level for each health or environmental variable in selected regression models of $\log _{e}$ of somatic cell count $(\operatorname{LnSCC})$ and clinical mastitis rate on stall type and environmental and management factors in Norwegian Dairy herds in 1994.

\begin{tabular}{lcccc}
\hline $\begin{array}{l}\text { Health and } \\
\text { environmental variables } \\
\text { (Maximum Model) }\end{array}$ & $\begin{array}{c}\text { LnSCC } \\
\text { Coefficients } \\
(\beta)\end{array}$ & $\begin{array}{c}\text { LnSCC } \\
\text { p-values } \\
\text { (t-test) }\end{array}$ & $\begin{array}{c}\text { Clinical Mastitis } \\
\text { Coefficients } \\
(\beta)\end{array}$ & $\begin{array}{c}\text { Clinical Mastitis } \\
\text { p-values } \\
\text { (t-test) }\end{array}$ \\
\hline $\begin{array}{l}\text { Intercept } \\
\text { LnCow year }\end{array}$ & 5.1786 & & 50.4297 & \\
$\begin{array}{l}\text { Milk production } \\
\text { Culling rate }\end{array}$ & 0.1503 & 0.00 & -5.9132 & 0.108 \\
Pasture & -0.00008687 & 0.00 & 0.1742 & 0.025 \\
Year built & & & & 0.07126 \\
$\begin{array}{l}\text { Type } \\
\text { Floor/Bedding }\end{array}$ & -0.0070 & 0.05 & -16.7999 & 0.002 \\
Litter & 0.0757 & 0.25 & -3.0864 & 0.033 \\
$\begin{array}{l}\text { Connection cellar } \\
\text { Clean cow }\end{array}$ & 0.0353 & & & \\
Stall hygiene & 0.0996 & 0.07 & & \\
Hoof trimming & & 0.00 & & \\
Hoof condition & & & & \\
Clip cow & & & & \\
Barn insulation & 0.0492 & 0.16 & & \\
Multiple R & & & 0.22 & \\
Multiple R & 0.33 & & 0.05 & \\
\hline
\end{tabular}

a Only variables indicated with coefficients and p-values were selected in the final models.

Table 6. Comparison of adjusted mean $\log _{e}$ of somatic cell count (LnSCC) among categories of cow cleanliness in Norwegian dairy herds in free stall or tie stall barns, in 1994.

\begin{tabular}{lccc}
\hline $\begin{array}{l}\text { Variable } \\
\text { Category }\end{array}$ & Sample size & $\begin{array}{c}\text { Adjusted mean } \\
\text { (cells per ml) }\end{array}$ & Somatic Cell Count \\
\hline 1. Very Good & 98 & $4.82^{\mathrm{a}}$ & 123,500 \\
2. Good & 350 & $4.95^{\mathrm{bc}}$ & 141,000 \\
3. Average & 105 & $5.02^{\mathrm{c}}$ & 151,000 \\
4. Poor & 7 & $5.12^{\mathrm{a}, \mathrm{b}, \mathrm{c}}$ & 167,500 \\
\hline
\end{tabular}

Adjusted means with a superscript in common are not statistically different from each other at a level of significance of $5 \%$ overall comparisons.

herds, as was noted for comparison of their crude means.

Table 9 illustrates the differences in adjusted mean FS-index among categories of cow cleanliness. Herds scoring 'average' on cow clealiness had an adjusted mean FS-index of 76.8 which was significantly lower than the adjusted mean FS-index of 83.4 for herds scoring 'good' $(\mathrm{p}<0.05$, t-test).

\section{Ketosis}

The overall mean ketosis rate was 5.9 reported 
Table 7. Comparison of adjusted mean clinical mastitis rates among 3 categories of Floor/Bedding type between Norwegian dairy herds in free stall or tie stall barns in 1994.

\begin{tabular}{lcc}
\hline Variable category & Sample size & Adjusted mean \\
\hline $\begin{array}{l}\text { 1. Concrete } \\
\text { 2. Rubber mat in some stalls other stalls concrete }\end{array}$ & 253 & $51.4^{\text {a }}$ cases per 100 cow-years. \\
$\begin{array}{l}\text { 3. Other (all rubber mat } n=75, \text { litter bed } \\
\quad n=204, \text { wood } n=7 \text {, other } n=2)\end{array}$ & 19 & $49.1^{\text {a,b }}$ cases per 100 cow-years. \\
$\quad$ & 288 & $45.2^{\text {b }}$ cases per 100 cow-years \\
\hline
\end{tabular}

a Adjusted means with a superscript in common are not statistically different from each other at a level of significance of $5 \%$. (t-test).

Table 8. Regression coefficients and significance level for each independent variable in selected regression model of fertility status index ${ }^{\mathrm{a}}$ (FS-index) on stall type and environmental and management factors in Norwegian dairy herds in 1994.

\begin{tabular}{lcc}
\hline $\begin{array}{l}\text { Independent } \\
\text { variables } \\
\text { (Max Model) }\end{array}$ & $\begin{array}{c}\text { FS-index } \\
\text { Coefficients }(\beta)\end{array}$ & $\begin{array}{c}\text { FS-index } \\
\text { p-values } \\
\text { (t-test) }\end{array}$ \\
\hline $\begin{array}{l}\text { Intercept } \\
\text { LnCowyear }\end{array}$ & 28.3966 & \\
$\begin{array}{l}\text { Milk production } \\
\text { Culling rate }\end{array}$ & 0.0050 & 0.00 \\
$\begin{array}{l}\text { Pasture } \\
\text { Year built }\end{array}$ & & \\
$\begin{array}{l}\text { Type } \\
\text { Clean cow }\end{array}$ & 14.7700 & 0.00 \\
Stall hygiene & -3.5025 & 0.03 \\
$\begin{array}{l}\text { Grain } \\
\text { Ketosis }\end{array}$ & & \\
Multiple R & & \\
Multiple $\mathrm{R}^{2}$ & 0.24 & \\
\hline
\end{tabular}

${ }^{\text {aFS}}$-index is defined in the "Materials and methods section".

b Only variables indicated with coefficients and p-values were selected in the final model.

cases per 100 cow-years. Of the 59 tie stall herds, 36 reported ketosis in 1994 (61\%), compared with 205 of 533 free stall herds (38\%). Relative risk for the tie stall group versus free stall group was 1.59 (95\% C.I. 1.26; 2.00, Chisquare $=11.20, \mathrm{p}<0.001)$.
Table 9. Comparison of adjusted mean fertility status index ${ }^{\mathrm{a}}$ (FS-index) among categories of cow cleanliness between Norwegian dairy herds in free stall and tie stall barns in 1994.

\begin{tabular}{lcc}
\hline Variable category & Sample size & Adjusted mean \\
\hline 1. Very Good & 104 & $82.5^{\mathrm{b}, \mathrm{c}}$ \\
2. Good & 351 & $83.4^{\mathrm{b}}$ \\
3. Average & 109 & $76.8^{\mathrm{c}}$ \\
4. Poor & 7 & $65.2^{\mathrm{b}, \mathrm{c}}$ \\
\hline
\end{tabular}

a FS-index is defined in the "Materials and methods section".

b,c Adjusted means with a superscript in common are not significantly different from each other at $5 \%$ level of significance (t-test).

\section{Discussion}

Our study demonstrated a significantly lower clinical mastitis rate in free stall herds than in a comparable group of tie stall herds, and a lower proportion of herds with reported cases of ketosis and higher mean FS-index among free stall barns than tie stall barns.

Important is the fact that only farms with automatic grain feeding were selected, and, therefore, extrapolation of results is limited only to farms using automatic grain feeding. Selection of herds with automatic grain feeding was done because we wanted to assess differences in FSindex and mean ketosis rate between free stall barns and tie stall barns, having controlled for 
grain feeding procedure. It is important to note that the clinical mastitis and ketosis rates measured in the present study are based on reported cases and may not necessarily reflect true incidence rates. Our results could be biased if there were different reporting rates between the 2 barn groups.

The squares of the sample correlation coefficients $\left(\mathrm{R}^{2}\right)$ in this study were $0.11,0.05$ and 0.06 for the regression of $\mathrm{LnSCC}$, Clinical Mastitis and FS-index, respectively, which are lower than in other studies among Norwegian dairy farms (Bakken 1981, Østerås \& Lund 1988). For example, an $\mathrm{R}^{2}$ of 0.11 in the regression model of LnSCC means that only $11 \%$ of the variation in LnSCC between herds could be explained by help of the health or environmental variables in the selected model as listed in Table 5. This means that there could be other variables that could explain the differences in SCC, clinical mastitis and FS-index between free stall and tie stall herds e.g. concentration of $\mathrm{CO}_{2}$ and ammonia, relative humidity, and temperature. However, because the number of tie stall barns $(n=59)$ was small, we had to exclude variables with many missing values to keep the sample size of tie stall barns sufficient large to compare with free stall barns.

For clinical mastitis and FS-index, the difference between free stall and tie stall barns remained highly significant in the respective multivariable models. In the regression model of LnSCC, barn type ( $\left.\beta_{\text {Type }}\right)$ was not statistically significant indicating no significant difference in adjusted mean LnSCC between free stall herds and tie stall herds, as was also true for the crude means. None of the significant independent variables explained the difference in FSindex or the lack of difference in LnSCC between free stall and tie stall herds because the regression coefficient of type of barn $\left(\beta_{\text {Type }}\right)$ changed only slightly when the variables were dropped from the selected regression model of
FS-index (Kleinbaum et al. 1987) or remained non-significant when the variables were dropped from the regression model of LnSCC. For the regression of clinical mastitis on the other hand, floor/bedding explained part of the difference in clinical mastitis found between free stall and tie stall herds because the coefficient of type of barn $\left(\beta_{\text {Type }}\right)$ increased by $15.6 \%$ in absolute value(from -16.8 to -19.4 ) when floor/bedding was dropped from the selected model. The majority of the free stall barns had floor/bedding classified as litter bed or rubber mat $(288$ of $533=54 \%)$ while the majority of the tie stall barns had a concrete floor (45 of 59 $=76 \%$ ). Since more mastitis was found in barns with a concrete floor compared to litter bed, rubber mat or wood this could explain part of the relatively large differences in clinical mastitis found between the 2 types of barns.

The $25 \%$ lower mean clinical mastitis rate in the free stall barns compared to the tie stall barns is in agreement with Bakken (1981), who found an approximately $30 \%$ lower clinical mastitis rate in free stall barns than in tie stall barns. Significant differences in frequencies of mastitis between large and small herds and differences in frequencies due to hygienic standard have been described (Solbu 1983, Hoare 1972). No associations between clinical mastitis and herd size and hygiene were demonstrated in the present study; however, low SCC was associated with clean cows and small herds as estimated by number of cow years. $(\mathrm{p}<0.01)$. It is important to note that the correlation between clinical mastitis and culling rate and between clinical mastitis and floor/bedding were significant at the 5 per cent level but not at the 1 per cent level of significance, thus indicating that a relatively large sample size was necessary to detect the association between these 2 variables and clinical mastitis and care should be excercised when interpreting the importance of the result. 
Culling rates in Norwegian dairy farms are relatively high. One would perhaps expect a lower risk of mastitis when the herds have a high culling rate, and hence might have a lower mean cow age. However, the positive association between culling rate and clinical mastitis found in this study might indicate that in herds with high rates of mastitis, the farmers tried to solve their problems by increasing the culling rate, but still had higher risk of clinical mastitis.

No significant difference in LnSCC was found between free stall and tie stall barns, which was expected. The most important factor predicting SCC was cow cleanliness, which indicated that the hygienic standard of the cows had a significant impact on udder health. However, no such association was found between SCC and stall hygiene.

Herds with high SCC had lower milk production than herds with low SCC ( $<<0.01)$, which is in agreement with other studies (Raubertas et al. 1982, Tyler et al. 1989, Jones et al. 1984). However, the regression coefficient for Milk production was low (Table 5) meaning that an increase in milk production was associated with a small decrease in SCC. If all the other variables in the model were kept constant at their mean levels, herds with average production level of $5000 \mathrm{~kg}$ per cow year on average would have SCC of 158800 cells per ml compared to 133500 for herds with average production levels of $7000 \mathrm{~kg}$ per cow years (16\% reduction in SCC).

The FS-index is a commonly used tool to assess fertility status at the farm level. Many farmers are interested in the index and attempt to obtain as high an FS-index as possible. The index is influenced by calving interval, return rate and number of services per inseminated cow or heifer. The goal is for each cow to give birth every year, (calving interval $\leq 365$ days), with as few inseminations as possible. The significantly higher FS-index in free stall herds suggested that estrus detection may be easier for cows free moving in the free stall barns than in tie stall barns.

The mean ketosis rate of 5.9 reported cases per 100 cow years in this study was considerably lower than the average rate for all herds in the Dairy Cow Control for 1994, which reported 18.4 cases per 100 cow years. Even though we selected only farms with automatic grain feeding, we still had significantly higher proportion of herds with reported cases of ketosis among tie stall barns compared to free stall barns. The rate of ketosis was not used in the analysis of difference between the 2 types of barns because more than half of the herds did not report ketosis at all and small herds might have had a higher influence on the mean ketosis rate than large herds. For more complete studies of ketosis, more data are needed (e.g. a longer followup period ) to obtain sufficient cases for analysis. When veterinary treatment is recorded in the health cards, the results of the test for ketone bodies in milk by means of the nitroprusside reaction (Ketotest ${ }^{\circledR}$ ) is often noted but not recorded. A need also exists for collection of more specific data regarding type of feeding and feed quality which could be potential confounding factors for the relationship between type of barns and incidence of ketosis.

Both the lower disease rates and the higher Fertility Status measured in the present study favor free stall herds over tie stall herds. None of the environmental variables measured in the study, except floor/bedding, was found to affect the relationship between barn type and the clinical mastitis, SCC and FS index. Further research is necessary to determine whether free stall herds have lower disease rates and higher fertilitystatus index than tie stall herds in general, and if so, why. 


\section{References:}

Bakken G: Environment and Bovine Udder Diseases in the Loose Housing System for Dairy Cows with Reference to Relevant Data from the Cowhouse System. Acta Agric. Scand.1981, 31, 445-451.

Bakken $G$ : The Relationship between Environmental Conditions and Bovine Udder Diseases in Norwegian Dairy Herd. Acta Agric. Scand. 1982, 32, 23-31.

Dixon WJ: BMDP Statistical Software Manual. University of California Press. Vol 2, 1992.

Hoare RJT, Roberts EA: Investigations in Mastitis Problem Herds 2. Effect of Herd Size, Shed Type, Hygiene and Management Practices. Aust. Vet. J. 1972, 48, 661-663.

Jones GM, Pearson RE, Clabaugh GA, Heald CW: Relationships Between Somatic Cell Counts and Milk Production. J. Dairy Sci. 1984, 67, 18231831.

Kleinbaum DG, Kupper LL, Muller KE: Applied Regression Analysis and Other Multivariable Methods. Duxbury Press, 1987 second Edition. pp 169-175, 314-340.

Raubertas RF, Shook GE: Relationship Between Lactation Measures of Somatic Cell Concentration and Milk Yield. J. Dairy Sci. 1982, 65, 419-425.

Riemann HP, Bjerke Larssen R, Simensen E: Ketosis in Norwegian Dairy Herds - some Epidemiological Associations. Acta Vet. Scand., 1985, 26, 482-492.

Solbu H: Disease recording in Norwegian dairy cattle. I. Disease incidences and non-genetic effects on mastitis, ketosis and milk fever. $Z$. Tierz. Zuechtungssbiol. 1983, 100,139-157.

Tyler JW, Thurmond MC, Lasslo L: Relationship Between Test-day Measures of Somatic Cell Count and Milk Production in California Dairy Cows. Can. J. Vet. Res. 1989, 53, 182-187.

Østerås $O$, Lund A: Epidemiological Analysis of the Associations between Bovine Udder Health and Housing. Prev. Vet. Med. 1988, 6, 79-80.

Østerås $O$ : Disease and Feeding in Norway. Acta Agric. Scand. 1993, Suppl. 89, 23-25.

Østerås $O$ : Registrering av faste innredninger og klima i fjøs for mjølkeproduksjon.(Registration of arrangements and climate in barns for milk production) Tinetrykk 14/91.

Østerås $O$, Tørud E, Waage S, Mørk T, Landsverk K: Helsetjenesten for Storfe, N-1430 Ås, Norway, Årsrapport 1994. (Norwegian Cattle Health Service, Annual report 1994).

\section{Sammendrag}

Sammenligning av ketose, klinisk mastitt, somatisk celletall og reproduksjonsstatus mellom båsfjøs og løsdriftsfjøs $i$ norske storfebesetninger med automatisk kraftfôrtildeling.

Forskjeller i frekvensen av ketose og klinisk mastitt, gjennomsnittlig celletall og fruktbarhetsstatus (FStall) mellom løsdriftsbesetninger og båsbesetninger ble undersøkt i relasjon til ulike miljøfaktorer blant Norske storfebesetninger med automatisk kraftfórtildeling.

Båsbesetningene hadde mer klinisk mastitt, (gjennomsnittlig 61.6 tilfeller pr 100 årskyr versus 46.4 tilfeller pr 100 årskyr $(\mathrm{p}<0.01)$ ), høyere andel av besetninger med ketose, (relativ risk $=1.59$, $(\mathrm{p}<0.01)$ ), og lavere FS-tall, (gjennomsnittlig 67.3 versus $82.8(\mathrm{p}<0.01))$. Ingen signifikant forskjell $\mathrm{i}$ gjennomsnittlig celletall ble funnet mellom de 2 gruppene av storfebesetninger $(\mathrm{p}=0.32)$.

Store besetninger hadde høyere $\log _{e}$ av geometrisk middel celletall enn små besetninger $(p<0.01)$, og besetninger med høyt celletall hadde lavere melkeproduksjon enn besetninger med lavt celletall $(p<0.01)$. Besetninger med "svært godt" reinhold av kyrne hadde signifikant lavere gjennomsnittlig celletall enn besetninger som hadde "middels" eller "godt" reinhold av kyrne $(\mathrm{p}<0.05)$. Besetninger i fjøs med betong-golv hadde gjennomsnittlig 51.4 tilfeller av klinisk mastitt pr 100 årskyr, $14 \%$ mer enn besetninger med gummimatte, strøseng eller tre (45.2 tilfeller pr 100 årskyr $(\mathrm{p}<0.05))$. Besetninger med høy melkeproduksjon hadde høyere FS-tall enn besetninger med lav melkeproduksjon $(\mathrm{p}<0.01)$.

Den lavere sjukdomfrekvens og høyere fruktbathetsstatus målt $\mathrm{i}$ denne undersøkelsen favoriserer løsdriftsbesetninger framfor båsbesetninger.

(Received September 19, 1996; accepted May 28, 1997).

Reprints may be obtained from: J.P. Valde, Brinken 4, N-6320 Isfjorden, Norway. E-mail: jpvalde@online.no, tel: +47 71225420 , fax: +4771226030. 